\title{
Study the Morphometry of Fresh and Cryopreserved Murrah Bull Spermatozoa
}

\author{
Raveshwar S Rana*, Isha Slathia, Ravinder S Rana \\ Veterinary College Mhow, University of Jammu, Govt Degree College Doda, India
}

Received January 12, 2020; Revised May 11, 2020; Accepted May 20, 2020

Copyright@2020 by authors, all rights reserved. Authors agree that this article remains permanently open access under the terms of the Creative Commons Attribution License 4.0 International License

\begin{abstract}
Artificial insemination with frozen - thawed spermatozoa was introduced in most of the developing countries more than three decades ago, yet it has not been successfully applied in large scale (Anzar et al., 2003). More than 50\% spermatozoa are usually injured by the cryopreservation process (Watson, 1995) injuries due to cryopreservation and more likely due to the increased solute concentration and the formation of intracellular and extracellular ice crystals during cryopreservation (Mazur, 1984) leading to a significant decline in semen quality and alterations in sperm morphometrix. Therefore, the present study was designed to study cryopreservation of buffalo semen and the effect of semen cryopreservation on determinant like semen fertility viz. sperm morphometry. Forty-eight semen samples collected from eight Murrah buffalo bulls maintained at Central semen station, Bhopal were included for the study of physic-morphological characters of neat and cryopreserved semen. Various measurements of the sperm head (length, width, base, ellipticity, elongation, head shape and area) and sperm tail (length of Midpiece and length of tail) were recorded in neat and cryopreserved semen. The average sperm measurements recorded were $7.24 \pm 0.06,4.26 \pm 0.05,2.65$ $\pm 0.79,11.92 \pm 1.53,43.12 \pm 2.79,61.97 \pm 0.50,25 \pm 0.07$, $19.13 \pm 2.58,0.59 \pm 0.01$, and $59.07 \pm 0.94$, respectively. There was a significant $(\mathrm{P}<0.05)$ decline of sperm head length, head width, midpiece length, tail length, total length and head area during the process of cryopreservation. However, no significant difference between width at base, ellipticity, head shape and elongation of the spermatozoa in neat and cryopreserved semen was recorded.
\end{abstract}

Keywords Cryopreservation, Murrah, Morphometry

\section{Introduction}

Buffalo has been an important animal species of Indian subcontinent since prehistoric time. It contributes substantially in terms of milk, meat and hide to the national economy. The world buffalo population is 152 million (FAO, 2003) distributed in 40 countries as 20 recognized breeds and this wonderful animal is slowly becoming recognized as the world's most important animal species especially in the countries where it exist in large numbers. India is a source of some of the best riverine breeds of buffaloes. Murrah, Nili-Ravi and Surti enjoy a dominant position among breeds noted for milk production. Bhadawari is reported to have high milk fat and Jaffarabadi is the heaviest of all the Indian buffalo breeds. The buffalo breeds of Indian subcontinent play important roles as producers of milk, draught power, dung and other value-added products. However, one of the major constraints for full exploitation of the productive potential of buffalo has been its inherently low reproductive efficiency. Artificial insemination with frozen - thawed spermatozoa was introduced in most of the developing countries more than three decades ago, yet it has not been successfully applied in large scale (Anzar et al., 2003). Advances in cryopreservation of bull spermatozoa have not kept pace with the advances that occurred in other reproductive technologies. More than 50\% spermatozoa are usually injured by the cryopreservation process (Watson,1995) injuries due to cryopreservation are more likely due to increasing solute concentration and the formation of intracellular and extracellular ice crystals during cryopreservation (Mazur, 1984) leading to significant decline in semen quality and alterations in sperm morphometrix. Only minimal changes in protocols for processing and freezing bull semen have been implemented in the past 20 years. This limited rate of progress is due to lack of complete understanding of the factors and interactions that alter spermatozoa viability upon processing, freezing and thawing. Straw are highly sensitive to temperature changes for their high surface to volume ratio. Thawing procedure is very important in terms of its impact on the reanimation of spermatozoa. Several trials have been carried out to decide most ideal 
thawing procedure for frozen semen. The post thaw fertilizing ability of spermatozoa is greatly affected by protocols such as thawing temperature and duration. Considering the importance of minimizing damage to the spermatozoa during cryopreservation process and need of accurate assessment of the sperm fertility in implementation of any artificial insemination programme, the present study was conducted with the following objective to study the morphometrix of fresh and cryopreserved Murrah bull spermatozoa.

\section{Materials and Methods}

\subsection{Experimental Design}

The present study was conducted in the Department of Animal Reproduction, Gynaecology \& Obstetrics, College of Veterinary Science \& Animal Husbandry, Mhow and central semen station, Bhopal. Eight Murrah buffalo bulls maintained under identical and optimal conditions of feeding and management in Central Semen Station, Bhopal were included in the study.

\subsection{Method of Sperm Collection and Preservation}

Fourty eight semen samples (six samples from each Murrah buffalo bull) were collected at Central Semen Station, Bhopal by artificial vagina method as described by Tomar (1997) in the morning hour, at 72 hours interval. Immediately after collection, neat semen evaluation was done and semen was subjected to examination filling, sealing, equilibration and cryopreservation as per the standard procedure using automated filling and sealing machine, cold handling cabinet and programmable biofreezer.

\subsection{The following Parameter was Studied in Fresh and Frozen Semen}

Sperm Morphometrix

Sperm morphometrix was studied in each sample to study the difference of sperm morphometrix in neat and frozen semen. Sperm were examined (1000 X magnification) with a Trinocular Research Phase Contrast Microscope (Manufactured by Leica Microsystems Shanghai, China) fitted with a high resolution digital CCD camera (still image resolution $=768 \_576$ pixels) and analyzed with imaging software (Leica DME Images plus 2.0; Leica DME China Group, Ltd., Shanghai). The system was first calibrated with images of standard length for known magnifications and measurement accuracy of 0.1 $\mathrm{mm}$. Various measurements of the sperm head (length, width, base, ellipicity, elongation, head shape and area) and sperm tail (length of Midpiece and length of tail) were recorded.

(i) Sperm head length (ii) Sperm head width (At the widest portion)

(iii) Width at base

(iv) Midpiece length

(v) Tail length

(vi) Total length

(vii) Head area (A) $=1.5-0.081 \times \mathrm{B} 2+0.64 \times \mathrm{w} \times \mathrm{L}$

(viii) Ellipticity $(\mathrm{L}-\mathrm{W}) /(\mathrm{L}+\mathrm{W})$

(ix) Elongation $\mathrm{W} / \mathrm{L} \times 100(\%)$

(x) Head shape (Width: Length ratio)

\subsection{Statistical Analysis}

The data were subjected to statistical analysis as per methods described by Snedecor and Cochran (1994). Pair ' $\mathrm{t}$ ' test was applied to compare different characterstics of neat and frozen.

\section{Results}

\subsection{Sperm Head Length}

The head length of the eight Murrah bulls MB I, MB II, MB III, MB IV, MB V, MB VI, MB VII and MB VIII were $7.30 \pm 0.682$, 7.35 $\pm 0.04,7.46 \pm 0.05,7.65 \pm 0.05,7.38 \pm 0.05$, $7.63 \pm 0.04,7.37 \pm 0.04$ and $7.60 \pm 0.05$ with an overall average of $7.47 \pm 0.05 \mu$. Significantly $(\mathrm{P}<0.05)$ higher sperm head length was recorded in bull MB IV, VI \& VIII as compared to the other bulls in the present study.

\subsection{Sperm Head Width}

The average head width (mean $\pm \mathrm{SE}$ ) of the Murrah bulls MB I, MB II, MB III, MB IV, MB V, MB VI, MB VII and MB VIII were $4.33 \pm 0.05,4.38 \pm 0.05$, 4.58 \pm 0.04 , 4.39 \pm 0.05 , $4.43 \pm 0.04,4.45 \pm 0.05,4.53 \pm 0.05$ and $4.33 \pm 0.04 \mu$, respectively. The overall average of the eight bulls was $4.43 \pm 0.04 \mu$. There was significant $(\mathrm{P}<0.05)$ between bulls and between ejaculates variations of sperm head width in the present study. Bulls MB III and MB VII recorded significantly $(\mathrm{P}<0.05)$ higher head width as compared to the other bulls in the current study.

\subsection{Width at Base}

The width at base (mean \pm SE) of the Murrah bulls MB I, MB II, MB III, MB IV, MB V, MB VI, MB VII and MB VIII recorded in the present study was $2.83 \pm 0.06$, $2.57 \pm 0.04,2.62 \pm 0.05,2.57 \pm 0.04,2.70 \pm 0.10,2.62 \pm 0.06$, $2.67 \pm 0.47$ and $2.56 \pm 0.53$, respectively with an overall average of $2.66 \pm 0.07 \mu$. Significantly $(\mathrm{P}<0.05)$ higher width at base was recorded in bull MB I as compared to the other bulls in the present study.

\subsection{Sperm Midpiece Length}

The midpiece length of the Murrah buffalo bulls MB I, MB II, MB III, MB IV, MB V, MB VI, MB VII and MB VIII in the present study was $12.21 \pm 0.18,12.22 \pm 0.08$, 
$12.2 \pm 0.18, \quad 12.16 \pm 0.08, \quad 11.73 \pm 0.21, \quad 12.16 \pm 0.17$, $12.57 \pm 0.08$ and $12.06 \pm 0.18 \mu$, respectively. The overall average of midpiece length of all the eight Murrah bulls was $12.17 \pm 0.14 \mu$. In the present study significantly lower $(\mathrm{P}<0.05)$ sperm midpiece length was recorded in bull $\mathrm{MB}$ $\mathrm{V}$ as compared to MB I, II, III, IV and VII. No significant difference was, however, recorded between bulls MB V. VI and VIII.

\subsection{Sperm Tail Length}

The tail length (mean $\pm S E$ ) of the Murrah bulls MB I, MB II, MB III, MB IV, MB V, MB VI, MB VII and MB VIII recorded in the present study was $44.18 \pm 0.31$, $43.70 \pm 0.33, \quad 43.75 \pm 0.22, \quad 43.59 \pm 0.25, \quad 43.26 \pm 0.24$, $43.48 \pm 0.26,45.04 \pm 0.30,42.69 \pm 0.58$ and $43.63 \pm 0.43 \mu$, respectively with an overall average of $43.63 \pm 0.43 \mu$. The mean length tail of Murrah buffalo bulls spermatozoa in the present study was recorded to be significantly $(\mathrm{P}<0.05)$ higher in MB VII as compared to the other bulls. There was significant $(\mathrm{P}<0.05)$ difference between sperm tail length of MB I and MB VIII.

\subsection{Total Sperm Length}

The total sperm length of the Murrah buffalo bulls MB I, MB II, MB III, MB IV, MB V, MB VI, MB VII and MB VIII in the present study was $63.73 \pm 0.36,63.28 \pm 0.62$, $62.82 \pm 0.70, \quad 63.41 \pm 0.26, \quad 62.38 \pm 0.07, \quad 63.27 \pm 0.32$, $65.01 \pm 0.34$ and $62.36 \pm 0.63 \mu$, respectively. The overall average of total sperm length of all the eight Murrah bulls was $63.28 \pm 0.36 \mu$. Bull MB VII showed significantly
$(\mathrm{P}<0.05)$ higher total sperm length as compared to the other bulls in the present study.

\subsection{Sperm Ellipticity}

The mean \pm SE of ellipticity of spermatozoa of the eight Murrah buffalo bulls MB I, MB II, MB III, MB IV, MB V, MB VI, MB VII and MB VIII recorded in the present study was $0.26 \pm 0.07, \quad 0.25 \pm 0.05, \quad 0.24 \pm 0.05, \quad 0.27 \pm 0.06$, $0.25 \pm 0.01, \quad 0.26 \pm 0.01, \quad 0.24 \pm 0.33$ and $0.27 \pm 0.01$, respectively. The overall average of the eight bulls recorded was $0.26 \pm 0.02$. In the present study significant difference $(\mathrm{P}<0.05)$ between bulls and ejaculate differences in ellipticity of spermatozoa was recorded. Bulls MB IV and MB VIII showed significantly higher ellipticity as compared to bulls MB II, III, V and VII. No significant difference of ellipticity was, however, recorded between bulls MB I, MB IV, MB VI and MB VIII.

\subsection{Sperm Head Area}

The head area of the Murrah buffalo bulls MB I, MB II, MB III, MB IV, MB V, MB VI, MB VII and MB VIII recorded in the present study was $21.67 \pm 0.33,21.94 \pm 0.28$, $23.21 \pm 0.27, \quad 22.82 \pm 0.30, \quad 22.23 \pm 0.23, \quad 23.05 \pm 0.29$, $22.70 \pm 0.44$ and $22.36 \pm 0.01$, square micron respectively. The overall average of Head area of spermatozoa of the eight Murrah bulls was 22.49 \pm 0.29 square micron. Significantly $(\mathrm{P}<0.05)$ higher sperm head area was recorded in the bulls $\mathrm{MB}$ III and VI as compared to the bulls MB I, II and V.

Table 1. Sperm morphometry parameters of neat semen

\begin{tabular}{|c|c|c|c|c|c|c|c|c|c|}
\hline $\begin{array}{c}\text { Bulls } \\
\ldots \ldots \ldots \ldots \ldots \ldots . . . . . . . . . \\
\text { Morphometric } \\
\text { parameters }\end{array}$ & MB I & MB II & MB III & MB IV & MB V & MB VI & MB VII & MB VIII & $\begin{array}{l}\text { Overall } \\
\text { average }\end{array}$ \\
\hline $\begin{array}{l}\text { Head Length } \\
(\mu)\end{array}$ & $\begin{array}{c}7.30^{\mathrm{a}} \\
\pm 0.682\end{array}$ & $\begin{array}{l}7.35^{\mathrm{a}} \\
\pm 0.04\end{array}$ & $\begin{array}{l}7.46^{\text {ac }} \\
\pm 0.05\end{array}$ & $\begin{array}{l}7.65^{\mathrm{b}} \\
\pm 0.05\end{array}$ & $\begin{array}{l}7.38^{\mathrm{a}} \\
\pm 0.05\end{array}$ & $\begin{array}{l}7.63^{\mathrm{b}} \\
\pm 0.04\end{array}$ & $\begin{array}{l}7.37^{\mathrm{a}} \\
\pm 0.04\end{array}$ & $\begin{array}{l}7.60^{\mathrm{bc}} \\
\pm 0.05\end{array}$ & $\begin{array}{c}7.47 \\
\pm 0.05\end{array}$ \\
\hline Head Width $(\mu)$ & $\begin{array}{l}4.33^{\mathrm{a}} \\
\pm 0.05 \\
\end{array}$ & $\begin{array}{l}4.38^{\mathrm{a}} \\
\pm 0.05 \\
\end{array}$ & $\begin{array}{l}4.58^{\mathrm{bc}} \\
\pm 0.04 \\
\end{array}$ & $\begin{array}{l}4.39^{\mathrm{ac}} \\
\pm 0.05 \\
\end{array}$ & $\begin{array}{l}4.43^{\mathrm{ac}} \\
\pm 0.04 \\
\end{array}$ & $\begin{array}{l}4.45^{\mathrm{ac}} \\
\pm 0.05 \\
\end{array}$ & $\begin{array}{l}4.53^{\mathrm{bc}} \\
\pm 0.05 \\
\end{array}$ & $\begin{array}{l}4.33^{\mathrm{a}} \\
\pm 0.04 \\
\end{array}$ & $\begin{array}{c}4.43 \\
\pm 0.04 \\
\end{array}$ \\
\hline $\begin{array}{c}\text { Width at Base } \\
(\mu)\end{array}$ & $\begin{array}{l}2.83^{\mathrm{a}} \\
\pm 0.06 \\
\end{array}$ & $\begin{array}{l}2.57^{\mathrm{bc}} \\
\pm 0.04 \\
\end{array}$ & $\begin{array}{l}2.62^{\mathrm{bc}} \\
\pm 0.05\end{array}$ & $\begin{array}{l}2.57^{\mathrm{bc}} \\
\pm 0.04 \\
\end{array}$ & $\begin{array}{l}2.70^{\mathrm{ac}} \\
\pm 0.10 \\
\end{array}$ & $\begin{array}{l}2.62^{\mathrm{bc}} \\
\pm 0.06 \\
\end{array}$ & $\begin{array}{l}2.67^{\text {ac }} \\
\pm 0.47 \\
\end{array}$ & $\begin{array}{l}2.56^{\mathrm{bc}} \\
\pm 0.53\end{array}$ & $\begin{array}{c}2.66 \\
\pm 0.07 \\
\end{array}$ \\
\hline $\begin{array}{l}\text { Midpiece } \\
\text { length }(\mu)\end{array}$ & $\begin{array}{c}12.21^{\text {ad }} \\
\pm 0.18\end{array}$ & $\begin{array}{l}12.22^{\mathrm{ad}} \\
\pm 0.08\end{array}$ & $\begin{array}{l}12.2^{\text {ad }} \\
\pm 0.18\end{array}$ & $\begin{array}{l}12.16^{\text {ad }} \\
\pm 0.08\end{array}$ & $\begin{array}{l}11.73^{\mathrm{bc}} \\
\pm 0.21\end{array}$ & $\begin{array}{c}12.16^{\text {ad }} \\
\pm 0.17\end{array}$ & $\begin{array}{l}12.57^{\mathrm{a}} \\
\pm 0.08\end{array}$ & $\begin{array}{c}12.06^{\mathrm{dc}} \\
\pm 0.18\end{array}$ & $\begin{array}{l}12.17 \\
\pm 0.14\end{array}$ \\
\hline Tail Length $(\mu)$ & $\begin{array}{l}44.1^{\text {ad }} \\
\pm 0.31\end{array}$ & $\begin{array}{l}43.70^{\text {ac }} \\
\pm 0.33\end{array}$ & $\begin{array}{l}43.75^{\text {ac }} \\
\pm 0.22\end{array}$ & $\begin{array}{l}43.59^{\text {ac }} \\
\pm 0.25\end{array}$ & $\begin{array}{l}43.26^{\mathrm{ac}} \\
\pm 0.24\end{array}$ & $\begin{array}{l}43.48^{\text {ac }} \\
\pm 0.26\end{array}$ & $\begin{array}{l}45.04^{\mathrm{d}} \\
\pm 0.30\end{array}$ & $\begin{array}{c}42.69^{\text {bc }} \\
\pm 0.58\end{array}$ & $\begin{array}{l}43.63 \\
\pm 0.43\end{array}$ \\
\hline Total length $(\mu)$ & $\begin{array}{l}63.73^{\mathrm{a}} \\
\pm 0.36\end{array}$ & $\begin{array}{l}63.28^{\mathrm{a}} \\
\pm 0.62\end{array}$ & $\begin{array}{l}62.82^{\mathrm{a}} \\
\pm 0.70\end{array}$ & $\begin{array}{l}63.41^{\mathrm{a}} \\
\pm 0.26\end{array}$ & $\begin{array}{l}62.38^{\mathrm{a}} \\
\pm 0.07\end{array}$ & $\begin{array}{l}63.27^{\mathrm{a}} \\
\pm 0.32\end{array}$ & $\begin{array}{l}65.01^{\mathrm{a}} \\
\pm 0.34\end{array}$ & $\begin{array}{l}62.36^{\mathrm{a}} \\
\pm 0.63\end{array}$ & $\begin{array}{l}63.28 \\
\pm 0.36\end{array}$ \\
\hline Ellipticity & $\begin{array}{l}0.26^{\mathrm{ac}} \\
\pm 0.07\end{array}$ & $\begin{array}{l}0.25^{\mathrm{a}} \\
\pm 0.05\end{array}$ & $\begin{array}{c}0.24^{\mathrm{a}} \\
\pm 0.05\end{array}$ & $\begin{array}{l}0.27^{\text {bc }} \\
\pm 0.06\end{array}$ & $\begin{array}{l}0.25^{\mathrm{a}} \\
\pm 0.01\end{array}$ & $\begin{array}{l}0.26^{\mathrm{ac}} \\
\pm 0.01\end{array}$ & $\begin{array}{l}0.24^{\mathrm{a}} \\
\pm 0.33\end{array}$ & $\begin{array}{l}0.27^{\mathrm{bc}} \\
\pm 0.01\end{array}$ & $\begin{array}{c}0.26 \\
\pm 0.02\end{array}$ \\
\hline Head Area & $\begin{array}{l}21.67^{\mathrm{a}} \\
\pm 0.33\end{array}$ & $\begin{array}{l}21.94^{\text {ac }} \\
\pm 0.28\end{array}$ & $\begin{array}{c}23.21^{\text {bd }} \\
\pm 0.27\end{array}$ & $\begin{array}{c}22.82^{\text {bc }} \\
\pm 0.30\end{array}$ & $\begin{array}{l}22.24^{\mathrm{ac}} \\
\pm 0.23\end{array}$ & $\begin{array}{c}23.06^{\text {bd }} \\
\pm 0.29\end{array}$ & $\begin{array}{c}22.70^{\text {ad }} \\
\pm 0.44\end{array}$ & $\begin{array}{c}22.37^{\text {ad }} \\
\pm 0.01\end{array}$ & $\begin{array}{l}22.49 \\
\pm 0.29\end{array}$ \\
\hline Head Shape & $\begin{array}{l}0.59^{\text {adc }} \\
\pm 0.08\end{array}$ & $\begin{array}{l}0.60^{\text {adc }} \\
\pm 0.06\end{array}$ & $\begin{array}{l}0.61^{\mathrm{a}} \\
\pm 0.06\end{array}$ & $\begin{array}{l}0.57^{\text {bc }} \\
\pm 0.07\end{array}$ & $\begin{array}{l}0.60^{\text {ad }} \\
\pm 0.07\end{array}$ & $\begin{array}{c}0.58^{\mathrm{C}} \\
\pm 0.01\end{array}$ & $\begin{array}{c}0.61^{\mathrm{a}} \\
\pm 0.06\end{array}$ & $\begin{array}{l}0.57^{\text {bc }} \\
\pm 0.08\end{array}$ & $\begin{array}{c}0.59 \\
\pm 0.07\end{array}$ \\
\hline Elongation & $\begin{array}{c}59.48^{\text {ace }} \\
\pm 0.85\end{array}$ & $\begin{array}{c}59.79^{\text {ace }} \\
\pm 0.71\end{array}$ & $\begin{array}{l}61.61^{\mathrm{a}} \\
\pm 0.66\end{array}$ & $\begin{array}{c}57.51^{\text {bc }} \\
\pm 0.75\end{array}$ & $\begin{array}{c}60.18^{\text {ace }} \\
\pm 0.71\end{array}$ & $\begin{array}{c}58.38^{\mathrm{ce}} \\
\pm 0.69\end{array}$ & $\begin{array}{l}61.56^{\mathrm{a}} \\
\pm 0.08\end{array}$ & $\begin{array}{c}57.24^{\text {dce }} \\
\pm 0.86\end{array}$ & $\begin{array}{l}59.49 \\
\pm 0.78\end{array}$ \\
\hline
\end{tabular}

Different superscripts within a row indicates significant difference $(\mathrm{P}<0.05)$ 


\subsection{Sperm Head Shape}

The head shape (mean $\pm \mathrm{SE}$ ) of the Murrah bulls MB I, MB II, MB III, MB IV, MB V, MB VI, MB VII and MB VIII recorded in the present study was $0.59 \pm 0.08$, $0.59 \pm 0.06,0.61 \pm 0.06,0.57 \pm 0.07,0.61 \pm 0.07,0.58 \pm 0.01$, $0.61 \pm 0.06$ and $0.57 \pm 0.08$, respectively with an overall average of $0.59 \pm 0.07$. There was significant $(\mathrm{P}<0.05)$ between bulls and ejaculate variation in the sperm head shape in the present study.

\subsection{Sperm Head Elongation}

The Elongation of spermatozoa in the semen of eight bulls in the present study averaged $59.66 \pm 0.85,59.79 \pm 0.71$, $61.61 \pm 0.66, \quad 57.50 \pm 0.75, \quad 60.18 \pm 0.71, \quad 58.38 \pm 0.69$, $61.56 \pm 0.08$ and $57.24 \pm 0.86$, respectively for MB I, MB II, MB III, MB IV, MB V, MB VI, MB VII and MB VIII bulls. The average concentration of the sperm of all the eight bulls was $59.49 \pm 0.78$. Significantly $(\mathrm{P}<0.05)$ higher values for sperm head elongation was recorded in bulls MB III and MB VII as compared to MB IV, VI and VIII. No significant difference between bulls MB I, II, IV, V, VI and VIII was, however, recorded in the present study

\subsection{Cryopreserved Semen}

Table 2. Sperm morphometric parameters of cryopreserved semen

\begin{tabular}{|c|c|c|c|c|c|c|c|c|c|}
\hline $\begin{array}{c}\text { Bulls } \\
\text {................ } \\
\text { Morphometri } \\
\text { c parameters }\end{array}$ & MB I & MB II & MBIII & MB IV & MB V & MB VI & MB VII & MB VIII & $\begin{array}{l}\text { Overall } \\
\text { average }\end{array}$ \\
\hline head Length & $\begin{array}{l}7.07 \pm \\
0.09^{\mathrm{a}}\end{array}$ & $\begin{array}{l}7.26 \pm \\
0.55^{\mathrm{a}}\end{array}$ & $\begin{array}{l}7.22 \pm \\
0.05^{\mathrm{a}}\end{array}$ & $\begin{array}{l}7.26 \pm \\
0.05^{\mathrm{a}}\end{array}$ & $\begin{array}{l}7.05 \pm \\
0.06^{\mathrm{a}}\end{array}$ & $\begin{array}{l}7.36 \pm \\
0.08^{\mathrm{b}}\end{array}$ & $\begin{array}{l}7.31 \pm \\
0.06^{\mathrm{b}}\end{array}$ & $\begin{array}{l}7.35 \pm \\
0.05^{\mathrm{b}}\end{array}$ & $\begin{array}{c}7.24 \pm \\
0.06\end{array}$ \\
\hline head Width & $\begin{array}{l}4.23 \pm \\
0.05^{\mathrm{ab}}\end{array}$ & $\begin{array}{l}4.19 \pm \\
0.04^{\mathrm{a}}\end{array}$ & $\begin{array}{l}4.44 \pm \\
0.06^{\mathrm{b}}\end{array}$ & $\begin{array}{l}4.22 \pm \\
0.05^{\mathrm{a}}\end{array}$ & $\begin{array}{l}4.28 \pm \\
0.06^{\mathrm{ab}}\end{array}$ & $\begin{array}{l}4.19 \pm \\
0.05^{\mathrm{a}}\end{array}$ & $\begin{array}{l}4.31 \pm \\
0.05^{\mathrm{ab}}\end{array}$ & $\begin{array}{l}4.25 \pm \\
0.05^{\mathrm{ab}}\end{array}$ & $\begin{array}{c}4.26 \pm \\
0.05\end{array}$ \\
\hline Width at Base & $\begin{array}{l}2.59 \pm \\
0.39^{\mathrm{ab}} \\
\end{array}$ & $\begin{array}{c}2.51 \\
\pm 0.04^{\mathrm{a}} \\
\end{array}$ & $\begin{array}{l}2.75 \pm \\
0.04^{\mathrm{ab}} \\
\end{array}$ & $\begin{array}{l}2.53 \pm \\
0.09^{\mathrm{ab}} \\
\end{array}$ & $\begin{array}{l}2.66 \pm \\
0.04^{\text {ab }} \\
\end{array}$ & $\begin{array}{c}2.57 \pm \\
0.1^{\mathrm{ab}} \\
\end{array}$ & $\begin{array}{l}2.75 \pm \\
0.08^{\mathrm{b}} \\
\end{array}$ & $\begin{array}{l}2.5 \pm \\
0.05^{\mathrm{a}} \\
\end{array}$ & $\begin{array}{c}2.65 \pm \\
0.79 \\
\end{array}$ \\
\hline $\begin{array}{c}\text { Midpiece } \\
\text { length }\end{array}$ & $\begin{array}{c}12.07 \pm \\
0.09^{\mathrm{a}} \\
\end{array}$ & $\begin{array}{c}11.94 \pm \\
0.11^{\mathrm{ab}} \\
\end{array}$ & $\begin{array}{c}11.72 \pm \\
0.20^{\mathrm{bc}} \\
\end{array}$ & $\begin{array}{c}11.81 \pm \\
0.08^{\mathrm{ab}} \\
\end{array}$ & $\begin{array}{c}11.48 \pm \\
0.47^{\mathrm{b}} \\
\end{array}$ & $\begin{array}{c}12.10 \pm \\
0.10^{\mathrm{ac}} \\
\end{array}$ & $\begin{array}{c}12.06 \pm \\
0.08^{\mathrm{ac}} \\
\end{array}$ & $\begin{array}{c}11.87 \pm \\
0.09^{\mathrm{ab}} \\
\end{array}$ & $\begin{array}{c}11.92 \pm \\
1.53 \\
\end{array}$ \\
\hline $\begin{array}{l}\text { Sperm Tail } \\
\text { Length }\end{array}$ & $\begin{array}{c}43.03 \pm \\
0.34^{\mathrm{ab}}\end{array}$ & $\begin{array}{c}43.26 \pm \\
0.33^{\mathrm{a}}\end{array}$ & $\begin{array}{l}43.21 \pm \\
0.36^{\text {ab }}\end{array}$ & $\begin{array}{c}42.70 \pm \\
0.25^{\mathrm{ab}}\end{array}$ & $\begin{array}{c}43.52 \pm \\
0.32^{\mathrm{a}}\end{array}$ & $\begin{array}{c}42.15 \pm \\
0.34^{\mathrm{b}}\end{array}$ & $\begin{array}{c}43.70 \pm \\
0.36^{\mathrm{a}}\end{array}$ & $\begin{array}{c}43.31 \pm \\
0.41^{\mathrm{ab}}\end{array}$ & $\begin{array}{c}43.12 \pm 2 . \\
79\end{array}$ \\
\hline $\begin{array}{l}\text { Total sperm } \\
\text { length }\end{array}$ & $\begin{array}{c}62.16 \pm \\
0.39^{\mathrm{a}}\end{array}$ & $\begin{array}{c}62.53 \pm \\
0.3^{\mathrm{a}}\end{array}$ & $\begin{array}{c}62.17 \pm \\
0.4^{\mathrm{a}}\end{array}$ & $\begin{array}{c}61.77 \pm \\
0.3^{\mathrm{a}}\end{array}$ & $\begin{array}{c}61.91 \pm \\
0.4^{\mathrm{a}}\end{array}$ & $\begin{array}{c}61.70 \pm \\
0.3^{\mathrm{a}}\end{array}$ & $\begin{array}{c}61.53 \pm \\
0.36^{\mathrm{a}}\end{array}$ & $\begin{array}{c}63.01 \pm \\
0.61^{\mathrm{a}}\end{array}$ & $\begin{array}{c}61.97 \pm \\
0.5\end{array}$ \\
\hline $\begin{array}{c}\text { head } \\
\text { Ellipticity }\end{array}$ & $\begin{array}{l}0.24 \pm \\
0.09 \mathrm{a}\end{array}$ & $\begin{array}{l}0.26 \pm \\
0.06 \mathrm{~b}\end{array}$ & $\begin{array}{l}0.24 \pm \\
.0 .01 \mathrm{a}\end{array}$ & $\begin{array}{l}0.26 \pm \\
0.04 \mathrm{~b}\end{array}$ & $\begin{array}{l}0.24 \pm \\
0.01 \mathrm{a}\end{array}$ & $\begin{array}{l}0.27 \pm \\
0.06 \mathrm{~b}\end{array}$ & $\begin{array}{l}0.26 \pm \\
0.01 \mathrm{~b}\end{array}$ & $\begin{array}{l}0.27 \pm \\
0.01 \mathrm{~b}\end{array}$ & $\begin{array}{c}0.25 \pm \\
0.07\end{array}$ \\
\hline head area & $\begin{array}{c}18.56 \pm \\
0.36^{\mathrm{a}}\end{array}$ & $\begin{array}{c}18.98 \pm \\
0.28^{\mathrm{ab}}\end{array}$ & $\begin{array}{c}19.57 \pm \\
0.31^{\mathrm{b}}\end{array}$ & $\begin{array}{c}19.10 \pm \\
0.29^{\mathrm{ab}}\end{array}$ & $\begin{array}{c}18.71 \pm \\
0.36^{\mathrm{ab}}\end{array}$ & $\begin{array}{c}19.27 \pm \\
0.2^{\mathrm{ab}}\end{array}$ & $\begin{array}{c}19.35 \pm \\
0.33^{\mathrm{ab}}\end{array}$ & $\begin{array}{c}19.32 \pm \\
0.39^{\mathrm{ab}}\end{array}$ & $\begin{array}{c}19.13 \pm \\
2.58\end{array}$ \\
\hline head Shape & $\begin{array}{c}0.60 \pm \\
0.01^{\mathrm{a}} \\
\end{array}$ & $\begin{array}{l}0.57 \pm \\
0.07^{\mathrm{b}} \\
\end{array}$ & $\begin{array}{c}0.60 \pm \\
0.01^{\mathrm{a}} \\
\end{array}$ & $\begin{array}{l}0.58 \pm \\
0.07^{\mathrm{ab}} \\
\end{array}$ & $\begin{array}{c}0.61 \pm \\
0.01^{\mathrm{a}} \\
\end{array}$ & $\begin{array}{l}0.56 \pm \\
0.01^{\mathrm{b}} \\
\end{array}$ & $\begin{array}{l}0.59 \pm \\
0.01^{\mathrm{ab}} \\
\end{array}$ & $\begin{array}{c}0.57 \pm \\
0.01^{\mathrm{b}} \\
\end{array}$ & $\begin{array}{c}0.59 \pm \\
0.01 \\
\end{array}$ \\
\hline $\begin{array}{c}\text { head } \\
\text { elongation }\end{array}$ & $\begin{array}{c}60.73 \pm \\
0.31^{\mathrm{ac}}\end{array}$ & $\begin{array}{c}57.93 \pm \\
0.76^{\mathrm{c}}\end{array}$ & $\begin{array}{c}60.93 \pm \\
0.83^{\mathrm{a}}\end{array}$ & $\begin{array}{c}58.14 \pm \\
0.71^{\mathrm{c}}\end{array}$ & $\begin{array}{c}60.42 \pm \\
1.01^{\mathrm{ac}}\end{array}$ & $\begin{array}{c}56.55 \pm \\
0.75^{\mathrm{b}}\end{array}$ & $\begin{array}{c}59.21 \pm \\
0.84^{\text {ac }}\end{array}$ & $\begin{array}{c}57.93 \pm \\
0.8^{\mathrm{c}}\end{array}$ & $\begin{array}{c}59.07 \pm \\
0.94\end{array}$ \\
\hline
\end{tabular}

Different superscripts within a row indicates significant difference $(\mathrm{P}<0.05)$.

Table 3. Sperm morphometric parameters of neat and cryopreserved semen

\begin{tabular}{|c|c|c|}
\hline Morphometric parameters & Neat Semen & Post- thaw \\
\hline Head Length $(\mu)$ & $7.47 \pm 0.05^{\mathrm{a}}$ & $7.24 \pm 0.06^{\mathrm{b}}$ \\
\hline Head Width $(\mu)$ & $4.43 \pm 0.04^{\mathrm{a}}$ & $2.26 \pm 0.05^{\mathrm{b}}$ \\
\hline Width at Base $(\mu)$ & $2.66 \pm 0.07^{\mathrm{a}} \pm 0.79^{\mathrm{a}}$ \\
\hline Midpiece length $(\mu)$ & $12.17 \pm 0.14^{\mathrm{a}}$ & $41.92 \pm 1.53^{\mathrm{b}}$ \\
\hline Tail Length $(\mu)$ & $43.63 \pm 0.43^{\mathrm{a}}$ & $61.97 \pm 0.55^{\mathrm{b}}$ \\
\hline Total length $(\mu)$ & $63.28 \pm 0.36^{\mathrm{a}}$ & $0.25 \pm 0.07^{\mathrm{a}}$ \\
\hline Ellipticity & $0.26 \pm 0.02^{\mathrm{a}}$ & $19.13 \pm 2.58^{\mathrm{b}}$ \\
\hline Head Area & $22.49 \pm 0.29^{\mathrm{a}}$ & $0.59 \pm 0.01^{\mathrm{a}}$ \\
\hline Head Shape & $0.59 \pm 0.07^{\mathrm{a}}$ & $59.07 \pm 0.94^{\mathrm{a}}$ \\
\hline Elongation & $59.49 \pm 0.78^{\mathrm{a}}$ & \\
\hline
\end{tabular}

Different superscripts within a row indicates significant difference $(\mathrm{P}<0.05)$ 


\subsection{Correlation between Sperm Morphometry Parameters}

The correlation between the different sperm morphometry parameters of Murrah semen is summarized in Table 1 and 2, on the basis of calculated correlation coefficient in neat as well as cryopreserved semen.

The neat semen tail length was significantly negatively correlated with head length ( $\mathrm{r}=-0.5259)$ and significantly positively correlated with head width $(\mathrm{r}=0.4720)$, width at base $(r=0.4026)$ and midpiece length $(r=0.7870)$. The head length was also significantly negatively correlated with width at base $(r=-0.5503)$ and midpiece length $(r=-0.3935)$. The head width was also significantly positively ( $\mathrm{r}=0.3378$ ) with sperm midipiece length. A highly significant correlation of total sperm length with head length $(r=0.3349)$, mid piece length $(r=0.9097)$ and tail length $(\mathrm{r}=0.960)$ was also recorded in the present study. Sperm cell ellipticity also had significantly negative correlation with sperm head length $(\mathrm{r}=-0.540)$ and width at base $(\mathrm{r}=-0.3211)$ and significant positive correlation with head width $(r=0.7303)$ and midpiece length $(r=0.9827)$ was also recorded in the present study. There was significant positive correlation of sperm midpiece length with sperm ellipticity $(r=0.9827)$ in neat semen. There was highly significant positive correlation of sperm head area with head length $(r=0.6348)$ and head width $(r=0.7333)$ and significant negative $(r=-0.5630)$ correlation with width at base. Midpiece length, tail length, total sperm length and Ellipticity of spermatozoa, however, did not significantly correlate with head area. A significant positive correlation of sperm head shape with head width $(r=0.7333)$, Ellipticity $(r=0.530)$ and head area $(r=0.566)$ and $a$ significant negative correlation of sperm head length $(r=-0.6979)$ with sperm head shape.

Sperm cell elongation was significantly negatively correlated with head length $(r=-0.7234)$ and ellipticity $(r=$ - 0.529) and significantly positively correlated with head width $(r=0.7333)$, head shape $(r=0.675)$ and head area $(r=0.4860)$. No significant correlation of sperm elongation was, however, observed with width at base, midpiece length, tail length, total sperm length and head area.

As evident from Table 2 and 3 similar trends were also observed in post thaw semen

\section{Discussion}

\subsection{Neat Semen Sperm Morphometric Parameters}

Sperm morphometry, in combination with other objective traits, can be useful for developing a fertility index. Particularly, sperm head abnormalities have been associated with lower fertility (Saake and White, 1972; Phetudomsinsuk et al., 2008). Routine sperm head morphology assessment are highly subjective and sperm morphometry promises enormous potential for evolving as a possible objective and accurate tool for prediction of bull fertility.

\subsection{Sperm Head Length}

The sperm head length (mean $\pm \mathrm{SE}$ ) recorded in the present study $(7.47 \pm 0.05 \mu)$ was in compliance to several other reports in the past (Aggrawal et al., 2007; Roy et al., 2008). Comparatively higher sperm head length was recorded in Bos indicus $(8.3 \mu)$ and Bos taurus $(8.9 \mu)$ in the past (Belleti et al., 2005). Ciftci and Zulkadir (2010) also recorded longer sperm heads in HF bulls (14.25 $\mu$ ). These differences may be attributed to differences in species and breed, different managemental conditions, different agro-climatic conditions and different season of study. There was significant between bull variation of sperm head length in the present study. The variation may be due to genetic variation in different populations by selection (Saini, 1994).

\subsection{Sperm Head Width}

The average overall sperm head width of $4.43 \pm 0.04$ was recorded in the present study with significant $(\mathrm{P}<0.05)$ variation between bulls and ejaculates. The mean sperm head width recorded in the present study is in fair compliance with several findings in the past (4.41 $\mu$ : Ali et al., 1976; $4.91 \mu$ : Kumar et al., 1977; $4.75 \mu$ : Aggrawal et al., 2007; $4.91 \mu$ : Roy et al., 2008). Lesser values for water buffalo sperm head width has also been recorded in the past (2.3 $\mu$ : Fischar and Gunzel, 1978). Fairly comparable values for cattle spermatozoa have been recorded in Bos taurus cattle in the past (4.71 $\mu$ : Saini, 1994; $4.39 \mu$ : Grevance et al., 1998; $4.5 \mu$ : Belleti et al., 2005) suggesting similarity in sperm head width of cattle and buffalo spermatozoa. The significant $(\mathrm{P}<0.05)$ difference between bulls recorded in the present study is in compliance with the findings of Katyar et al., 1989, who recorded significant between breed, males and slides differences in his study on Murrah, Surti and Mehsana bulls. Similar between bull variations have also been recorded in buffalo (Biswas, 1976; Pant and Mukherjee, 1973; Aggrawal, 2007), Cattle (Pandya et al., 1985; Saini, 1994) and bucks (Das and Sidhu, 1975; Kolachhapati, 1987). However, contrary results have also been reported by Ali (1976) and Mohan et al. (1981). The between bulls differences recorded in the present study and non compliance with few reports in the past may be due to the different genetics of bulls in these studies.

\subsection{Width at Base}

The overall mean \pm SE of width at base $(2.66 \pm 0.07 \mu)$ recorded in the present study is fairly comparable to the finding of $2.47 \mu$ recorded in the past (Roy et al., 2008). 
Limited literature is present in buffalo bulls for comparison of our results. In cattle smaller width at base $(1.966 \mu)$ has been recorded in the past (Saini, 1994) suggesting smaller head base in cattle as compared to buffaloes. In the present study significant $(\mathrm{P}<0.05)$ between bulls and between ejaculate variation was recorded. Similar between bull differences for this trait was also recorded in the past for buffalo (Deka, 1983), pigs (Batabyal, 1976), goat (Kolachhapati, 1987) and cattle (Saini, 1994). Whereas Bhusan (1989) reported no significant differences between bovine spermatozoa width at base. These variations between bulls might be due to either gentic or physiological factors governing spermatozoan growth. The nutrients in the germ cells are constant for all animals. Some germ cells have better growth potentiality, as determined by their haploid genotype, give larger spermatozoa while a low potential one give small spermatozoa.

\subsection{Midpiece Length}

The midpiece length recorded in the present study $12.17 \pm 0.14 \mu$ is in fair comparison to the $11.82 \mu$ (Rajawar and Mukherjee, 1969). Similar midpiece length has also been recorded in Hariana bulls (Saini, 1994). Significant differences between bulls and ejaculates have been observed in the present study which might be ascribed to the findings of Ciftci and Zulkadir (2010) that midpiece length is heritable and varies among the bulls within the same species. Similar between bull differences has also been reported in cattle (Pandya, 1985; Saini, 1994) and buffaloes (Mukherjee and bandhopadyay, 1982; Deka, 1983) in the past. The differences in spermatozoan attributes among bulls may be attributed to genetic differences in the physiological mechanism involved in the formation of spermatozoa. Between ejaculate variation in sperm midpiece length might be due to the fact that sperm midpiece also differs in the ejaculates of the same bull in different times.

\subsection{Sperm Tail Length}

A sperm tail length of $43.63 \pm 0.43 \mu$ was recorded in the present study. Similar finding were recorded by Vekataswamy and Vedanayagan, 1962, Roy et al., 2008 $(56.14 \mu)$ and Aggrawal et al. 2007 (57.02 $\mu$ ), however, recorded slightly greater sperm tail length in Murrah bulls. The differences may be due use of bulls of different genetic make up and different managemental and agroclimatic conditions. Significant $(\mathrm{P}<0.05)$ between bulls variation have also been recorded in sperm tail length in the present study which may be due to use of bulls of different age groups (Aggrawal et al., 2007).

\subsection{Total Sperm Length}

The total sperm length of $63.28 \pm 0.36 \mu$ recorded in the present study correspond well with the earlier reports in
Murrah bulls (63.42 $\mu$ : Vekataswamy and Vedanayagan, 1962; $63.73 \mu$ : Roy et al., 2008). Greater total sperm length, however, was recorded in Murrah (Aggrawal et al., 2007) and Surti (Kodagali et al., 1973) bulls in the past. Bull MB VII had longest spermatozoa as compared to other bulls in the experiment. Differences may be due to use bulls of different genetic makeup and age group.

\subsection{Sperm Head Ellipticity}

The sperm ellipticity recorded in the present study was $0.26 \pm 0.02$ in the present study was fairly comparable with the findings of Roy et al., 2008 (0.21). The ellipticity of buffalo bulls recorded in the present study was lesser than that recorded in Bos indicus (0.30) and Bos taurus (0.32) spermatozoa (Belleti et al., 2005). Similarly, higher ellipticity has also been recorded in bulls (Cifftci and Zulkadir, 2010). This is indicated by more elongated (elliptical) sperm heads and smaller length: width ratios. Significant $(\mathrm{P}<0.05)$ between bull variation was recorded in sperm head ellipticity of Murrah bulls in the present study. Similar between animals/ slide variations of sperm biometrics parameters have also been recorded in the past (Katyar, 1989) in buffalo bulls.

\subsection{Sperm Head area}

The sperm head area (mean \pm SE) recorded in the present study $\left(22.49 \pm 0.29 \mathrm{~mm}^{2}\right)$ complied well with the findings of Roy et al., 2008 in Murrah bulls and Kodagali et al., 1973 in Surti bulls. Significantly, greater sperm head area in Murrah bulls was, however, also recorded in the past (Aggrawal et al., 2007). These variations in head area may be due to genetic diversities in different populations. In Bos taurus $\left(32.9 \pm 3.6 \mu^{2}\right)$ and Bos indicus $\left(30.1 \pm 3.6 \mu^{2}\right)$ sperm head area (Beletti et al., 2005) was also greater than the sperm head area recorded in the present study indicating larger size of the sperm head area in cattle as compared to Murrah buffaloes. Saini (1994) also recorded similar results in neat semen of Hariana bulls. Significant $(\mathrm{P}<0.05)$ between bull difference recorded in the present study may also be due to difference in age and genetic make up of bulls used in the present study. Similar significant between bull variations were also recorded in cattle in the past (Saini, 1994) which might be due to variability of sperm nucleus in case of individual animals (Gledhill et al., 1970). So the differences recorded in the present study are biological in nature.

Between bulls variations have also been recorded in other domestic animals like cattle (Mukherjee and Singh, 1966; Pandya, 1976), buffaloes (Pant and Mukherjee, 1972), goat (Das and Sidhu, 1975) and pigs (Batabyal, 1976).

\subsection{Sperm Head Shape (Width: Length Ratio)}

The head shape of $0.59 \pm 0.07$ was recorded in Murrah 
bulls in the present study. Similar width length ratio was also recorded in the past (0.66: Tomar et al., 1962; 0.62: Rajawar and Mukherjee, 1969; 0.61: Ali, 1976; 0.59: Aggrawal et al., 2007). Higher, width:length ratio has also been recorded in cattle (Saini, 1994). Significant $(\mathrm{P}<0.05)$ between bull variations was reported for this attribute in the present study. Similar findings were recorded in cattle (Pandya et al., 1976; Bhusan, 1989), buffaloes (Ali, 1976, Mukherjee and Bandopadhyay, 1982, Deka, 1986) and goats (Kolachhapati, 1987). Non significant between bull differences was, however, also recorded in the past (Mohan et al., 1981). The shape of the spermatozoa was not influenced by the external forces on the spermatid nucleus but the phenomenon was genetically controlled and dependent upon the condensation of DNA and protein of the nucleus.

\subsection{Sperm Head Elongation}

The sperm head elongation of $59.94 \pm 0.78$ was recorded in Murrah bulls in the present study. Similar findings were also recorded in the past (Tomar et al., 1962; Rajawar and Mukherjee, 1969; Ali, 1976; Aggrawal et al., 2007). Higher, sperm head elongation has also been recorded in cattle (Saini, 1994). Significant $(\mathrm{P}<0.05)$ between bull variations was reported for this attribute in the present study. Similar findings were recorded in cattle (Pandya et al., 1976; Bhusan, 1989), buffaloes (Ali, 1976, Mukherjee and Bandopadhyay, 1982, Deka, 1986) and goats (Kolachhapati, 1987).

\subsection{Cryopreservation of Murrah Semen}

\section{Effect of Cryopreservation on Sperm Morphometry}

The mean sperm head length, width, midpiece length, tail length, total sperm length, ellipticity, head area, head shape and elongation in cryopreserved semen of Murrah bulls compared fairly well with the findings of Aggrawal et al. (2007). The Sperm head length, head width, midpiece length, tail length, total sperm length and head area decreased significantly $(\mathrm{P}<0.05)$ after freezing and thawing. The results in the present study are in compliance with the previous report in Bos taurus (Grevance et al., 1998; Guillen et al., 2007) and Bos indicus (Guillen et al., 2007) bulls. A significant between bulls and between ejaculate difference was observed in sperm morphometric dimensions of frozen thawed semen of Murrah bulls in the present study. Similar differences were also observed in case of bovine (Grevance et al., 1998) and caprine semen (Grevance et al., 1997). The differences in morphometric dimensions between neat and cryopreserved spermatozoa observed in the present study may be explained by changes in sperm chromatin structure. The surface area of sperm heads tended to decrease after cryopreservation and thawing, which might be attributed to changes in sperm chromatin structure. It was hypothesized that cryopreservation induces over condensation of sperm chromatin. A variety of spermatozoal injury, such as heat stress and cryopreservation can induce changes in sperm chromatin structure, resulting in acid induced denaturation (Blottner et al., 2001). Few studies have also associated abnormal chromatin structure with abnormal sperm head morphology (Gledhill et al., 1970; Grevance et al., 1998) and reduced fertility. However, it is difficult to interpret whether morphometric dimensions are associated with abnormal chromatin structure and reduced fertility as reports for direct comparison of effect of cryopreservation on sperm morphometric dimensions of Murrah bulls are lacking. Acrosomal exocytosis and osmotic changes may also be reason for alteration in sperm morphometric dimensions during the process of cryopreservation (Thomas et al., 1997; Blottner et al., 2001; Esteso et al., 2003). One possible hypothesis for the reduction of sperm head dimensions of spermatozoa of all bulls may be an increase in number of spermatozoa with acrosomal damage or loss occurred during cryopreservation and thawing (Thomas et. al., 1997). The proportion of acrosome reacted spermatozoa is also significantly increased during the process of cryopreservation and thawing (Chauhan et al., 1991). Cryopreservation may also be responsible for membrane damage of bovine spermatozoa (Valcarcel et al., 1994). Because the present study did not deal with morphology of the nucleus and acrosome separately, the role of these individual component could not be assessed for causing decrease in bull sperm head morphometric dimensions. However, the process of cryopreservation led to increase in the number of dead spermatozoa with the loss of acrosomal and plasma membranes during cell death (Esteso et al., 2006). Therefore, decrease of sperm head dimensions in the present study could, at least, partially be explained by damage or loss to the acrosome and increase in percentage of acrosome reacted spermatozoa, as cited by Grevance et al., 1998 and Guillen et al., 2007.

Reduction in seminal characterstics after post thaw incubation might be due to damage to plasma membrane this damage might have occurred due to continous accumulation toxic end product owing to increase oxidative metabolism resulting in increase concentration of peroxide formation in the medium with the increase in the number of dead spermatozoa (John et al., 1979) with the increase in perportion of dead spermatozoa the toxicity of the medium might have increase which might have cause further damage to spermatozoa. Contradictory reports of increased sperm head dimensions after cryopreservation and thawing, however, has also been reported in the past (Grevance et al., 1997). The differences may be due to differences in fixation technique, staining procedure, individual or species differences.

\subsection{Correlation between Seminal Traits}

In the present study a significant negative correlation of sperm tail length with sperm head length and significant 
positive correlation with head width, width at base and midpiece length was recorded. Increased midpiece length, resulting from more or larger mitochondria, results in greater energy required to achieve higher swimming speeds. Longer tails are also required for greater swimming speeds. A significantly negative correlation of sperm head length with width at base and midpiece length and significant positive correlation of sperm head width with sperm midipiece length was also recorded in the present study. Similar positive correlation between sperm head length and midpiece length was also reported in porcine (Gill et al., 2009). In contrast, a negative correlation of sperm head length with midpiece length has also been reported in the past (Humphries et al., 2008). Reports suggesting no significant correlation of sperm midpiece length and sperm head length are, however, also on records (Malo et al., 2006; Ciftci and Zulkadir, 2010). The highly significant positive correlation of total sperm length with head length, mid piece length and tail length recorded in the present study suggest that sperm with longer heads are associated with greater overall length.

The significant negative correlation of sperm head ellipticity with sperm head length and width at base and significant positive correlation with head width and midpiece length, in the present study are in compliance to the similar reports in porcine (Gill et al., 2009) where a significantly negative correlation of sperm head size with Ellipticity was reported. There was highly significant positive correlation of sperm head area with head length and head width and significant negative correlation with width at base suggesting that sperm cells with longer and broader heads are associated with greater areas. Sperm cell elongation was significantly negatively correlated with head length and ellipticity and significantly positively correlated with head width, head shape and head area. Similar negative correlation of sperm cell ellipticity with elongations was also reported in porcine spermatozoa (Gill et al., 2009). Whereas, few other studies suggest no correlation of sperm head dimensions with sperm cell ellipticity (Malo et al., 2006; Ciftci and Zulkadir, 2010). Reports of similar studies in buffaloes are either lacking or are scanty, therefore, further studies are warranted to confirm or negate our findings.

\section{Conclusions}

In the present study, there was a significant difference between bull variations was recorded in neat semen head length, head width, width at base, midpiece length, tail length, total sperm length, ellipticity sperm head area, sperm head shape and elongation.

There was a significant difference between bull and between ejaculate variation in all the sperm morphometrix parameters of the cryopreserved except variation in the total sperm length. There was significant decline of sperm head length, head width, midpiece length, tail length, total length and head area during the process of cryopreservation. Sperm conception was significantly negatively correlated with head length, head width, Width at base, Tail length and total sperm length and positively correlated with Ellipticity, head area head shape and elongation.

\section{REFERENCES}

[1] Aggrawal, R.A., S.P. Ahlawat, Y. Kumar, P.S Panwar, K. Singh and M. Bhargava. (2007). Biometry of frozenthawed sperm from eight breeds of Indian buffaloes (bubalus bubalis). Theriogenology, 68 (4): 682-680.

[2] Ajitkumar, G. C. Menon, C. Jaco, R. Thundathil, J. P Kastelic and H.W. Barkwema. (2011). Validating the assesstment of bull sperm morphology by veterinary practitioners. Can. Vet.J., 52(4): 407-408.

[3] Ali, S.Z. (1976). Studies on DNA and RNA content, morphological characteristics and some of the biochemical constituents of buffalo spermatozoa. Thesis Abstr., 3: 256-258.

[4] Amastalden, M., E. Oba, J.E.P. Santos, A.A. Ramos and L. Franz. (1994). Studies of qualitative and quantitative characteristics of bubaline semen. In: $4^{\text {th }}$ World Buffalo Congress, Sao Paulo, Brazil, 27-30, 3: 582-584.

[5] Anderson, M.J. and A.F. Dixson (2002). Motility and the midpiece in primates. Nature. 4(16): 496-499.

[6] Andrew, G.M. (1971). Seasonal changes in the quanitity and quality of semen of bulls of various breed. Sb. Rab. Leningr. Vet. Inst., 32:130-134.

[7] Anzar, M., U. Farooq, M. A. Mirza, M. Shahab and N. Ahmad. (2003). Factors affecting the efficiency of artificial insemination in cattle and buffalo in punjab, Pakistan. Pakistan Vet. J., 23: 106-113.

[8] Baker, F. N. and G.W. Salisbury (1963). Nuclear size of live and dead bovine spermatozoa. Nature (Lond.), 19(7): 820-822.

[9] Banas z ewska, D., S. Kondracki and A. Wysokinska (2008). Effect of sperm concentration on ejaculate for morphometric traits of spermatozoa of the pietrain breed boars. Central Euro. agri., 10 (4): 383-396.

[10] Barth, A.D. and R.J. Oko. (1989). Abnormal morphology of bovine spermatozoa. Willay Blackwell,London.,p 285.

[11] Basirov, E.B. (1964). Reproductive biology and artificial and artificial insemination in water buffaloes. Proc. $5^{\text {th }}$ Int. Congr. Anim. Reprod. And A.I., 4-5dec.Torento.

[12] Batabyal, A.K. (1976). Genetic effects on spermatozoa of pig (Sus domesticus). Ph.D. Thesis, Agra University, Agra.

[13] Bedi, k.S, R.K. Biswas and Y.G. Dugwekar. (1984). Fructolysis in semen and its relation to breeding performance in buffalo bulls. Indian J. Anim. Sci., 58(12): 1419-1423.

[14] Beatty, R.A. (1970). The genetics of the mammalian gamete. 
Biol. Rev. 45:p73.

[15] Belleti, M.E., Luciano da Fontoura Costa and M. P. Viana (2005). A comparison of morphometric characteristics of sperm from fertile Bos taurus and Bos indicus bulls in Brazil. Anim. Reprod. Sci., 85 (1): 105-116.

[16] Belorkar, P.M., A.J. Dhami, H.J. Decashri and S.B. Kodagali (1990). Studies on seminal and mensurational characteristics of spermatozoa and their interrelationships with freezability and fertility in crossbred bulls. PVK Research J. 14(2) : 165-168.

[17] Bhandari, N., R.A.S. Chauhan and A. Mathew (1982). Note on the effect of rate of freezing on the freezability of buffalo spermatozoa. Indian J. Anim. Sci., 52 (9): 812-813.

[18] Bhat, V.T., G. Monnappa, B.M. Dubly and M. Devraj (2002). Impact of age on frozen semen production potential in Murrah buffalo bulls. In: $9^{\text {th }}$ International Congress on Biotechnology in Animal Reproduction, Chennai.

[19] Bhat, V., T.G. Honnappa and B.M. Dubey (2004). Seasonal effects on seminal attributes in Murrah bulls under banglore agroclimatic conditions. Indian J. Anim. Reprod. 25(1): 23-24.

[20] Bhattacharya, P. (1974). Reproduction in the Husbandry and Health of the Domestic Buffaloes. FAO, Rome, 105p.

[21] Bhavsar, B.K., K.S. Patel, V.K. Kerur and S.B. Kodagali (1986). Seminal characters, freezability and fertility in Mehsana and Murrah buffalo bulls. Indian. J. Anim. Reprod. 7: 7-14.

[22] Bhoserekar, M.(1980). Studies on buffalo semen seasonal variation in semen characteristics. Indian Vet. J,. 57: 801-806.

[23] Bhosrekar, M.R., S. Mokashi, J.R. Purohit, S.B. Gokhle and B.R. Mangurkar (1991). Studies on the effect of deep freezing and seasons on the leakage aspartate amino trans aminase into extracellular medium and sperm morphology of Murrah buffalo bulls. Anim. Reprod. Sci.,26: 219-226.

[24] Bhusan, S. (1989). Genetic studies of spermatozoal sttributes in cattle. Ph.D. Thesis. I.V.R.I. Izatnagar, Barielly.

[25] Biswas, J. C. (1973). Phenogenitic studies on spermatozoan characterstics in cross breed cattle and their association with fertility. M.V.Sc Thesis. Agra University, Agra.

[26] Biswas, J. C., R. Kumar and N. S. Sidhu. (1976). A study of correlation between spermatozoa head shape and fertility in cross breed bulls. Paper presented in $64^{\text {th }}$ annual meeting of Indian science congress association, January 1977, Bhuvneshwar.

[27] Biswas, J.C., N.S. Sidhu and P.N Bhatt (1977). Studies on dimentional characterstics of spermatozoa of cross breed bulls in relation to fertility. Indian. J. Anim. Sci., 45(2): 919-923.

[28] Blottner, S., C. Warnke, A. Tuchscherer, V. Heinen and H. Torner (2001). Morphological and functional changes in stallion spermatozoa after cryopreservation during breeding and non breeding season. Anim. Reprod. Sci., 65: 75-88.

[29] Branton, C.D., G. Arensbourg and J.E. Johnston (1952). Semen production fructose content of semen and fertility of dairy bulls as related to sexual excitement. J. Dairy Sci.,35:
801-805.

[30] Campbell, R.C., J.L. Hancock and L. Rothschild (1956). Counting live and dead bull spermatozoa. J. Expert. Biol., 30: 40-49.

[31] Cardullo. R.A. and J.M. Baltz (1991). Metabolic regulation in mammalian sperm; mitochomdrial volume determines sperm length and flagellar beat frequency. Cell. Motil. Cytoskelton., 19: 180-188.

[32] Casey, P.J, C.G. Gravance, R.O. Davis, D.D Chabot and I.k.M Liu (1997). Morphometric difference in sperm head dimentions of fertile and subfertile stallions. Threiogenology, 47: 575-589.

[33] Chan, P.J., H.C.LD. Johannah U. Corselli, J.D. Jacobson, W.C. bPatton and A. King. (1999). Spermac stain analysis of human sperm acrosomes. Fert. Steril. 72: 124-128.

[34] Chauhan, R.A.S., N. Bhandari and A. Mathew (1991). Studies on deep freezing of buffalo semen. Indian. J. Anim. Reprod. 12(2): 123-125.

[35] Chen, Y., R.H. Foote, C. Tobback, L. Zhang and S.Hough,(1993). Survival of bull spermatozoa seeded and frozen at different rates in egg-yolk Tris and whole milk extenders. J. Dairy Sci., 76 (4): 1028-1034.

[36] Ciftci, H.B. and U. Zulkadir (2010). The correlation between bull sperm head dimensions and mitochondrial helix length. J. Anim. Vet. Advan., 9(7): 1169-1172.

[37] Crabo, B.G. and R.S. Jeyendran (1978). Biochemical characteristics of semen and its behaviour during freezing and thawing. Proceedings of the National seminar sponsored by FAO/SIDA/Govt. of India, held at NDRI, Karnal, Dec. 4 $-15,1978$ on buffalo reproduction and artificial insemination.

[38] Das,D. and N.S. Sidhu (1975). Biometrical studies on ram spermatozoa in Muzaffarnagri and Corriedale breeds of sheep(Ovis aries). Indian J. Hered. 7: 11-14.

[39] De, B. (1992). Studies on preservation of bovine semen in zwitter ion buffers. M.V.Sc. Thesis, IVRI, Izatnagar, India.

[40] Deka, N. N., A. K. Batabyal and R.P. Singh (1983) Multivariate analysis in the genetics of Murrah buffalo spermatozoan dimensional characterstics. Indian J. Diary Sci, 39(4); 503-505.

[41] Dhami, A.J. (1992). Comparative evaluation on certain processing procedures in deep freezing of cattle and buffalo semen under tropical climate. Ph.D. thesis, IVRI, Izatnagar, India.

[42] Dhami, A.J. and K.L.Sahni (1994).Comparative appraisal of physico-morphological and enzymatic attributes of semen and their inter relationship in ox and buffalo bulls. J. Appl. Anim. Res.,5: 13-20.

[43] Dhami, A.J. and K.L.Sahni, (1993). Evaluation of different cooling rates, equilibration periods and diluents for effects on deep freezing, enzyme leakage and fertility of taurine bull spermatozoa. Theriogenology, 40 (6): 1269-1280.

[44] AJ Dhami, M Greesh, KL Sahni(1998). Seasonal influence on the quality and freezability of semen of Friesian and Murrah buffalo bulls: Indian J. Anim. Reprod 19 (1), 55-58 
[45] Esteso,M.C., M.R.,Fernandez-Santos, A.J.Soler and J.J.Garde (2003). Head dimensions of cryopreserved red deer spermatozoa are affected by thawing procedure. Cryo. Letters., 24: 261-268.

[46] Food and Agriculture Organization (2003). Rome, Italy. www.fao.com

[47] Farrant, J. (1980). General observations on cell preservation. Ashwood- Smith, M.J. and Farrant, J. (eds) In Low Temperature Preservation in Medicine and Biology. Pitman Medical Kent, U.K., 1-17.

[48] Fischer, H. and A.R. Gunzel (1978). Semen collection and findings in the water buffalo (Bubalus buballis). Zuchthygiene. 13: 83-85.

[49] Foster, J., J. O. Almquist and R. C. Martig (1970). Reproductive capacity of beef bulls. IV. Changes in sexual behavior and semen characteristics among successive ejaculations. J. Anim. Sci., 30: p245.

[50] Foster, J., J.O. Almquist and R.C. Mestig (1971). Reproduction capacity of beef bulls changes in sexual behaviour and sexual characteristics among successive ejaculation. J. Anim. Sci., 30: 245-252.

[51] Garg, U.K. and R.K. Pandit (1983). Studies of some seminal attributes in relation to crossbred bulls. Indian J. Anim. Reprod., 4: 26-29.

[52] Gill, R.S..P.C. Gangwar, and O.P. Takar (1974). Seminal attributes in buffalo bulls as affected by different seasons. Indian J. Anim. Sci., 44 :415-418.

[53] Gledhill, B.L., I. Gustavsson and B. Henricson (1970). DNA content of presumed aneuploid spermatozoa. Heriditas., 65 : p291.

[54] Gokhale, S.B., M. Mustaque, N. Phadke, L. Dinodkar and G.S. Ambhore (2003). Studies on the effect of hydrogen ion concentration of extender on semen characters of Murrah buffalo bulls. Indian J. Anim. Reprod., 24(2): 158-160.

[55] Grevance, C.G., R. Viswanath, C. Pitt, D.L. Garner and P.J. Casey (1998). Effect of cryopreservation on bull sperm head morphometry. J. Androl., 19 (6): 704-709.

[56] Guenzel, A.R., H.J. Boehnke, J. Valencia, and M. Fischer (1979). Tiefgefrierung Von wasser bueffelsperma. Zuchthygiene, 14: 181-184.

[57] Guillen, J.R., D. González, J.J. Garde, M.C. Esteso, M.R. Fernández-Santos, J.E. Rodríguez-Gíl, N. Madrid-Bury and A. Quintero-Moreno (2007). Effects of cryopreservation on bull spermatozoa distribution in morphometrically distinct subpopulations. Reprod. Dom. Anim., 42 (4): 354-357.

[58] Gunarajsingam, D., H. Abeygunawardena, U.V. Kuruwita, E.B.K. Perera, B.M.A.O. Perera (1996). Seasonal variations in seminal and testicular characteristics in buffalo bulls. Role. Proceedings of regional symposium, Peradeniya,12-15 Nov. Sri Lanka., 309-320.

[59] Hadi, M. A. (1967). Mensuration of heads of spermatozoa of deoni breed. Indian Vet. J., 4: p229.

[60] Heuer, C. (1980). Versuche Zur Tiefgefrierkonservie rung von wasser bueffelsperma unfer Anwendung des Filtertestes zur Samenbeurteilung Tieraerztlichen Hochshule Hanover, Dissertation, $74 \mathrm{p}$.
[61] Hirai, M., A., A. Boersma, E. Hoeflich, J. Wolf, T.R. Foll, G. Aumuller and J. Braun (2001). Objectively measured sperm motility and sperm head morphometry in boars (sus scrofa) Relation to fertility and seminal plasma growth factors. $J$. Androl., 22: 104-110.

[62] Humphries, S., J. Evans and L.W. Simmons (2008). Sperm competition linking form to function. BMC Evol. Biol., 8: p319.

[63] John, G.W., N.L. Van Denmark, and J.R. lodge (1979) Physiology of Reproduction and Artificial Insemination of Cattle. $2^{\text {nd }}$ Edn. W.H. Freeman, Fan Francisco 385-479.

[64] Kapoor, P.D. (1973). Studies on semen characteristics of buffalo bulls. Indian J. Anim. Sci., 43(7): 573-578.

[65] Kodagali, S.B., B.K. Bhavsar and A.D. Deshpande (1973). Biometrics of surti buffalo spermatozoa. Indian Vet. J., 50: p 50.

[66] Kolachhapati, M.R. (1987). Phenogenetic studies on goat spermatozoa. M.Sc. Thesis, C.C.S. Haryana Agril. University, Hisar.

[67] Koonjaenak, S., V. Chanatinart, S. Aiumlamai, T. Pinyopumimintr and H. Rodriguez-Martinez (2006). Subtle membrane changes in cryopreserved bull semen in relation with sperm viability, chromatin structure, and field fertility. Theriogenology, 60: 743-758.

[68] Krajnc, A. (1964). Biometricsche untersuchungen an bullenspermien and deren bezeie hungen zur fruchtbarheit. Schr. Reihe Max-Planck-Inst. Tiersiicht., 20: p76.

[69] Kumar, S., K.L. Sahni and G. Mohan (1993). Freezing of buffalo semen in milk, tris and sodium citrate dilutors with different levels of yolk and glycerol in relation to $\mathrm{pH}$ of dilutors. Indian J. Anim. Sci., 63(5): 499-504.

[70] Lal, A. and K.P. Pant (1984). Dimentional characterstics of spermatozoa in relation to fertility of soviet merino Rams. Indian Vet. J., 61(8): 674-679.

[71] Lambrechts, H., F.E. Van Niekerk, W.A. Coetzer, S.W.P. Cloete and G. Horst Van der (1999). The effect of cryopreservation on the survivability, viability and motility of epididymal African buffalo (Syncerus Caffer) spermatozoa. Theriogenology, 52: 1241-1249.

[72] Light, R.J. and B.J. Restall (1971). Effect of site of insemination, sperm motility and genital tract contraction on transport of spermatozoa in the ewe. J. Reprod. Fertil., 26 : $1-13$

[73] Madden, F.W., H.A. Herman and E.R. Berousek (1947). The Relationship between Percentage of Live Spermatozoa and Motility, Longevity, and Fertility of Semen of Dairy Bulls. Mo. Agr. Expt. Sta. Research Bull ,3: p 407.

[74] Majid, M. A and A.B.M.M. Islam (1981). Phenotypic variation in size of spermatozoa in different breeds of cattle. Livestock Adviser., 6(5): 23-26.

[75] Mall, R., G. Mohan and S.K. Meur (1997). Differential cryoinjury to organelles and enzymes of spermatozoa during deep freezing of buffalo semen Implication on assessment of freezability. Buffalo J. 1: 43-54.

[76] Malo, A.F., M. Gomendio, J. Garde, B. Lang-Lenton, A.J. Soler and E.R.S. Roldan (2006). Sperm design and sperm 
function. Biol. Lett., 2: 246-249.

[77] Mann, T.(1964). The Biochemistry of Semen and of the Male Reproductive Tract. Springer-Verlag, Berlin.345p.

[78] Mann, T. and C.L. Mann (1981). Male Reproductive Function and Semen.Springer-Verlag. Berlin, $2^{\text {nd }}$ Edn.250p.

[79] Mazur, P. (1984). Freezing of living cell mechanisms and implications. Amer. J. Physio., 2(47): 125-142.

[80] Md, Shafi Ch. (1979). Semen freezing and artificial Insemination in buffalos in Pakistan. Anim. Prod. Health Rome, 13: 315-316.

[81] Mukherjee, D.P. and S.K. Bandopadhyay (1982). Discrimination between buffalo bulls by spermatozoan dimensions and daughter's performance. Indian J. Anim. Sci., 52: 880-885.

[82] Narayan, P., V.N. Reddy, P.A. Sharma, T.G. Honnappa, M. Devraj, A. Krishnaswamy and V.K. Arora (1999). Spermiogram and biochemical studies in Murrah buffalo bulls. Indian J. Anim. Reprod., 20 (2): 156-158.

[83] Nath, R. (1988). Cryopreservation of buffalo semen. M.V.Sc Thesis, G.B. Pant Univ. of Agri. \& Tech., Pantnagar, India.

[84] Nath, R., S.S. Tripathi, V.B. Saxena and R.P. Tripathi (1991). Tris diluents and freezability of buffalo semen. Indian Vet. J., 68 (2): 135-138.

[85] Nema, S.P. and S.B. Kodagali (1983). Studies on biometry of testis and its correlation to sperm producing ability in surti buffalo bulls. Indian J. Anim. Reprod. 4(1):89-91.

[86] Obi Reddy, A. (1975). Effect of genetic and non genetic factors on spermatozoan dimentional characterstics and proportion of live spermatozoa of buffalos. M.V.Sc. Thesis J.N.K.V.V. Jabalpur.

[87] Pace, M.M. and E.F.Graham (1974). Components in egg yolk which protects bovine spermatozoa during freezing. $J$. Anim. Sci., 39:p 114.

[88] Pampapathi, J., G. Mohan, S. Kumar and K.L. Sahni (1997). Effect of dilution rate and yolk level on preservability of Murrah buffalo semen. Indian J. Dairy Sci., 50: 352-358.

[89] Pandey, A.K. (2001). Effect of blood serum and caffeine on cryopreservation of buffalo spermatozoa. M.V.Sc. Thesis, G.B. Pant Univ. of Agri. and Tech., Pantnagar, India.

[90] Pandey, A.K., H.P. Gupta and V.B. Saxena (2001). Assessment of membrane integrity after cryopreservation of buffalo spermatozoa. In: XVII Annual convention and National seminar on Fertility management of Farm animals under adverse agro-climatic conditions, Jodhpur, India, p58.

[91] Pandya, D.K. (1976). Study on some economic traits and dimensional characteristics of spermatozoa of Jersey. Thesis Abstract, Haryana Agri. Univ., 4(1): 22-23.

[92] Pandya, D.K., K.S. Johar and A. Singh (1985). Study on dimentional characterstics of jersey bull spermatozoa. Indian Vet. J., 62(6): 494.

[93] Pant, K.P. and D.P. Mukherjee (1972). The effect of seasons on the sperm dimensions of buffalo bulls. J. Reprod. Fert., 29: 425-429.

[94] Pena, F.J., F. Saravia, M. Garcia- Herreros, I.
Nunez-Martinez and J.A. Tapia (2005). Identification of sperm morphometric subpopulations in two different portions of the boar ejaculate and its relation to post thaw quality. J. Androl., 26: 716-723.

[95] Perumal, P., A.K. Barik, D.N. Mohanty, R.K. Das and P.C. Mishra (2009). Seminal characteristics of Jersey crossbred bulls. In: XXV Annual Convention of ISSAR and International Symposium, Namakkal, $10^{\text {th }}-12^{\text {th }}$ November, 2009. p196.

[96] Petac, D. and M. Kosec (1989). Some morphological characterstics of bull spermatozoa and their effect in fertility. Zbornik Biotechniske Fakultete. Univerze Edvarda Kardelja V Ljubijani Veterinarstvo.,26 (1): 65-72.

[97] Phetudomsinsuk, K., K. Sirinarumitr, A. Laikul, A. Pinyopummin (2008). Morphology and head morphometric characters of sperm in Thai native crossbred stallions. Acta Veterinaria Scandinavica.,50:p41.

[98] Rasul, Z., N. Ahmad and M. Anzar (2001). Changes in motion characteristics, plasma membrane integrity and acrosome morphology during crypopreservation of buffalo spermatozoa. J. Androl., 22: 278-283.

[99] Roberts, S.J. (1982). Veterinary Obstetrics and Genital diseases. $2^{\text {nd }}$ Edn. Scientific Book Agency, Calcutta.550p.

[100] Roy, B., P.K. Nagpaul, P.K. Pankaj, T.K. Mohanty, V.S. Raina and A. Mishra (2008). Studies on Biometry of Sperm of Murrah Buffalo Bulls. Buffalo Bulletin, 27: 192-195.

[101] Roy, D.J. and M.R. Ansari (1973). Studies on freezability of buffalo spermatozoa using two freezing technique. Indian $J$. Anim. Sci., 43:1031-1033.

[102] Saacke, R.G. and J.M. White (1972). Semen quality tests and their relationship to fertility. Proc. IV Tech. Conf. Artif. Insemination Reprod.,20 (1):p 181.

[103] Saacke, R.G., J.M. De Jarnette, R.L. Nebel and S. Nadir (1991). Assessing bull fertility. In: Proceedings Society for Theriogenology., 56-69.

[104] Sahni, K. L. and A. Roy (1972). Deep freezing of buffalo semen. Indian Vet. J., 49: p 263.

[105] Saini, A. (1994). Morphometric studies on spermatozoa and cytogenic studies in Hariana bulls. PhD Thesis, C.C.S. Haryana agricultural university Hissar.

[106] Thomas, C.A., D.L. Garner, J.M. De-jarnette and C.E. Marshall (1997). Fluorometric assessment of acrosomal integrity and viability in cryopreserved bovine spermatozoa. Biol. Reprod., 45: 880-887.

[107] Tomar, S.S. and S.P. Singh (1996). Studies on reaction time and some seminal attributes and their interrelationship in Murrah buffalo bulls. Indian J. Anim. Res., 30 (1): 49-54.

[108] Tripathi, S.S. and V.B. Saxena (1983). Seasonal variation in quality and preservation of semen of Murrah bulls. Cherion, 12:193-199.

[109] Tuli, R.K. (1984). Seasonal variation in seminal characteristics of Murrah buffalo bulls. Livestock Adv.,9: 37-40.

[110] Valcarcel, A., M.A. De Las Heras, L. Perez, D.F. Moses and H. Baldassarre (1994). Fluorescent staining as a method 
of assessing membrane damage and post-thaw survival of ram spermatozoa. Theriogenology, 41: 483-489.

[111] Vale, W. G. (1997). News on reproduction biotechnology in Males. In: Proceedings of $5^{\text {th }}$ World buffalo Congress: 13-16 Oct., pp. 103-123, Caserta, Italy.

[112] Vale, W.G., I.M. Ohasi, H.F.L. Ribeiro and J.S. Sonsa (1991). Semen freezing and artificial insemination in the Amazon Valley. Buffalo J., 7 (2): 137-144. 49-152.

[113] Venkataswamy, V. and A.R. Vedanayagan (1962). Biometrics of spermatozoa of cattle. Indian Vet. J., 39: 287-291.

[114] Vyawahare, R., R.A.S. Chauhan, S.P. Nema and M.L.Porwal (1989). Studies on seminal attributes, enzyme leakage and preservability of buffalo semen. Indian Vet. J., $66: 1128-1132$.

[115] Wall, R.J. and R.H. Foote (1999). Fertility of bull sperm frozen and stored in clarified egg yolk -tris-glycerol extender. J. Dairy Sci., 82 (4): 817-821.

[116] Watson, P.F. (1995). Recent developments and concepts in the cryopreservation of spermatozoa and the assessment of their post-thawing function. Reprod. Fertil. Dev., 7: 871-891.

[117] Younis, M., H.A. Samad, N. Ahmad and I. Ahmad (1999). Fertility of frozen thawed semencollected from young adult and old buffalo bulls during low and peak breeding seasons. Pakistan Vet. J., 19 (2): 78-80

[118] Yudi, T. L., B. Yusuf, A. Purwantara, D. Sajuthi, S. Mulyono and J. Manansang (2008). Biometry of the External Reproductive Organ and Characteristics of Ejaculate of the Anoa (Bubalus sp.) Collected by Electroejaculator after Injected with HCG. Terakreditasi B. SK. Dikti., 32 (1): 1-11.

[119] Zelfel, S. (1964). Genological investigation on fertility in black pied bulls used for artificial insemination in the German. Kuhn Archiv., 77:241-287.

[120] Zemjanis, R. (1970). Diagnostic and therapeutic techniques in Animal Reproduction. $2^{\text {nd }}$ Edn., Williams and Wilkins, Baltimore.p145. 